\title{
Modeling Light InTERCEPTION ANd Distribution In MiXed CANOPY OF COMMON COCKLEBUR (Xanthium stramarium) IN COMPETITION WITH CORN
}

\author{
Modelagem de Interceptação e Distribuição de Luz em Dossel de Xanthium stramarium em \\ Competição com Milho
}

VAZIN, F. ${ }^{2}$, HASSANZADEH, M. ${ }^{2}$, MADANI, A. ${ }^{2}$, NASSIRI-MAHALLATI, M. ${ }^{3}$ and NASRI, M. ${ }^{4}$

\begin{abstract}
The aim of this study was to model light interception and distribution in the mixed canopy of Common cocklebur (Xanthium stramarium) with corn. An experiment was conducted in factorial arrangement on the basis of randomized complete blocks design with three replications in Gonabad in 2006-2007 and 2007-2008 seasons. The factors used in this experiment include corn density of 7.5, 8.5 and 9.5 plants per meter of row and density of Common cocklebur of zero, 2, 4, 6 and 8 plants per meter of row. INTERCOM model was used through replacing parabolic function with triangular function of leaf area density. Vertical distribution of the species' leaf area showed that corn has concentrated the most leaf area in layer of 80 to $100 \mathrm{~cm}$ while Common cocklebur has concentrated in $35-50 \mathrm{~cm}$ of canopy height. Model sensitivity analysis showed that leaf area index, species' height, height where maximum leaf area is seen (hm), and extinction coefficient have influence on light interception rate of any species. In both species, the distribution density of leaf area at the canopy length fit a triangular function, and the height in which maximum leaf area was observed was changed by change in density. There was a correlation between percentage of the radiation absorbed by the weed and percentage of corn seed yield loss $\left(\mathrm{r}^{2}=0.89\right)$. Ideal type of corn was determined until the stage of tasseling in competition with weed. This determination indicates that the corn needs more height and leaf area, as well as less extinction coefficient to successfully fight against the weed.
\end{abstract}

Keywords: modeling, competition, Common cocklebur, corn, light.

RESUMO - O objetivo deste estudo foi desenvolver um modelo de intercepção de luz e distribuição na copa mista do cardo comum (Xanthium stramarium) com o milho. Um experimento foi conduzido em arranjo fatorial com base no projeto de blocos completos randomizados com três replicações em Gonabad nas estações de 2006-2007 e 2007-2008. Os fatores usados neste experimento incluem a densidade do milho de 7,5, 8,5 e 9,5 plantas por metro de linha e densidade do cardo comum de zero, 2, 4, 6, e 8 plantas por metro de linha. O modelo INTERCOM foi usado através da substituição da função parabólica com função triangular da densidade da área da folha. A distribuição vertical da área das folhas das espécies mostrou que o milho concentrou a maior área foliar em camada de 80 a $100 \mathrm{~cm}$ enquanto o cardo comum concentrou em $35-50 \mathrm{~cm}$ de altura de copa. A análise da sensibilidade do modelo mostrou que o indice da área da folha, altura das espécies, altura onde a área máxima da folha é vista (hm), e coeficiente de extinção tem influência sobre a taxa de intercepção da luz em qualquer uma das espécies. Nas duas espécies, a densidade da distribuição da área da folha no comprimento da copa adequou-se a uma função triangular, e a altura na qual a área máxima da folha foi observada foi mudada pela mudança na densidade. Houve uma correlação entre a porcentagem da radiação absorvida pelas plantas daninhas e a porcentagem de perda de rendimento da semente do milho $\left(r^{2}=0,89\right)$. Otipo ideal de milho foi determinado até o estágio de borlamento em competição com plantas daninhas. Esta determinação indica que o milho necessita de mais altura érea foliar, assim como de menos coeficiente de extinção para lutar com sucesso contra as plantas daninhas.

Palavras-chave: modelo, competição, cardo comum, milho, luz.

1 Recebido para publicação em 18.5.2010 e na forma revisada em 3.9.2010.

${ }^{2}$ Islamic Azad University, Gonabad Branch, Gonabad, Iran, <Madani_ahad@yahoo.com>; ${ }^{3}$ Ferdosi University, Mashhad, Iran;

${ }^{4}$ Islamic Azad University, Varamin Branch, Varamin, Iran. 


\section{INTRODUCTION}

Light plays the most important role among all environmental factors affecting competition in mixed canopy (Keating \& Carberry, 1983). Most of differences observed in the yield of competing species in mixed culture are due to differences in the amount of light received and/ or its consumption efficiency (Sinoquet et al., 1996). Canopy structure is one important factor in determining the competitive ability of plants (Caldwell, 1987). The plant structure that is suitable for pure culture is not necessarily suitable for mixed culture. For example, although it is an advantage for a species in mixed culture, to have more leaf area index or more horizontal leaves above the canopy, it is not necessarily an advantage in pure culture (Rhodes \& Stern, 1978). Leaf angle, leaf area index, and leaf area distribution are traits with major role in light interception and consequently canopy photosynthesis (Anten \& Hirose, 1999; Hirose et al., 1997). However, those traits that lead to maximum canopy photosynthesis are not necessarily seen in each single plant. For example, photosynthetic capacity of canopy with vertical leaves is higher than horizontal leaves because more light will pass among the vertical leaves, reach lower layers, and lead to uniform distribution of light within the canopy. However, a crop with horizontal leaves will receive more light and have more photosynthesis when weeds have vertical leaves (Toller \& Guice, 1996). It is impossible to measure light interception by each species in the mixed canopy. So modeling of light interception process is considered as the most favorable method to determine the light received by any species (Berkowitz, 1988). In the past decades, several models have been proposed to predict the competition for light. Photosynthetic models express how light interception and consumption is done by the different species in the canopy (Hikosaka et al., 1999). Spitters \& Aerts (1983) proposed a model in which the canopy was divided into several layers, and light interception of each layer was calculated based on the contribution of leaf area to this layer. It is impossible to use light interception models in mixed canopy without describing the canopy structure and its effect on light interception by different species (Toller \& Guice, 1996). To simulate the light received by species of broadleaf weed of Common cocklebur (Xanthium stramarium), this study was performed in competition with corn in order to determine the amount of light received as well as the affecting factors.

\section{MATERIALS AND METHODS}

\section{Field experiments}

The experiment was performed in the growing seasons of 2005-2006 and 2006-2007 in the research farm of Islamic Azad University (Gonabad branch). The site is located at 34'21' North latitude, 58'41' East longitude, with an altitude of $1056 \mathrm{~m}$ above the sea level, in a land with loamy clay soil. The average annual rainfall is $142 \mathrm{~mm}$ in the region, and the annual absolute maximum and minimum temperatures are reported to be 24.1 and $10.8{ }^{\circ} \mathrm{C}$, respectively. The weather of this region has been determined cold and dry based on Emberger climate. The experiment was performed as factorial based on randomized complete blocks with three replications. In the first experiment, experiment factors include: corn density in three levels $(7.5,8.5,9.5$ plants per meter of row) and Common cocklebur density in five levels (zero, 2, 4, 6 and 8 plants per meter of row). The corn genotype used in both experiments was SC704. The experiment was carried out in an incremental form in which the corn density was fixed in each level while Common cocklebur density was variable. Urea fertilizer and ammonium phosphate fertilizer were used with rate of $150 \mathrm{~kg}$ per hectare (69 kg Nitrogen) and rate of $180 \mathrm{~kg}$ per hectare $(4.86 \mathrm{~kg}$ nitrogen), respectively. Ammonium phosphate fertilizer was mixed with the soil before planting, and urea fertilizer was used two times (50\% at planting and 50\% at emergence of male inflorescence). Plot size of $5 \times 6$ meter, having 6 rows and $0.75 \mathrm{~m}$ row spacing was used. Common cocklebur seeds which were passed one-year period inside the soil were used. Considering the fact that there is dormancy in the Common cocklebur seeds, the seed of Common cocklebur weed was treated by gibberlic acid during embryo culture technique. Before planting, the corn seeds were disinfected by using vitavax fungicide. In May 5th, planting was manually done when soil water content reached $75 \%$ of available amount. Planting depth was 5 to $6 \mathrm{~cm}$. Two to 
three seeds were planted at each interval based on the densities intended in project and thinned to one after seedling emergence (trifoliate stage). Furthermore, weed seeds were uniformly planted based on the intended density between the corn's rows. The first furrow irrigation was done in May 15th. The next irrigation took place as normal routine based on plant need and common irrigation cycle in the area where the experiment was located. Additional common cocklebur seedlings were removed by hand in order to obtain the desired densities. Undesired weeds were controlled by pulling and hoeing at frequent intervals. From three-leaf stage of corn to physiological maturity, sampling was done once every two weeks. In each sampling, plants were taken out with roots, and their height was measured after washing out the roots. Then plant leaves were separated, and their leaf areas were determined by leaf area meter device (LI-COR Model LI-3000A Portable). In the $84^{\text {th }}$ and $98^{\text {th }}$ days after planting, the vertical distribution of the species' leaf area was measured by measuring leaf area index in 9 layers of $20 \mathrm{~cm}(0-20,20-40,40-60,60-80$, 80-100, 100-120, 120-140, 140-160, 160$180 \mathrm{~cm}$ from soil level). For this reason, the plants in each sample were divided into $20 \mathrm{~cm}$ layers, and the leaves in each layer were separated. Then the areas of leaves were determined. All plants samples were taken from $30 \mathrm{~cm}$ of the inner for rows. To study the distribution of light in the canopy (120 days after planting), the radiation measuring device (SunScan model SS1-R3-BF3) was placed on a metal base having a movable adjustable clamp, and then the amount of light was measured in the top and bottom of each layer. Corn was hand-harvested from $2 \mathrm{~m}$ of the inner four rows to determine the grain yield. To measure the total biomass, samples were dried in oven with a temperature of $70{ }^{\circ} \mathrm{C}$ for $48 \mathrm{hr}$. For testing the validity and sensitivity of the model, t-student and chi square test were employed using Sigmaplot and SAS softwares. Drawings of diagrams were done by Excel or Quattroporo.

\section{Model structure}

Within a canopy, radiation from the top to bottom is exponentially reduced based on the following equation.

$$
I_{h}=(1-p) I_{0} \exp (-K L) \quad \text { Equation (1) }
$$

Where, $I_{h}=$ Amount of radiation in canopy's height $h$, in terms of joules per square meter of land per seconds; $I_{0}=$ Amount of radiation above the canopy (joules per square meters of land per second); $L=$ Cumulative leaf area index from top to bottom of canopy (square meter of leaf per square meter of land); $P=$ reflection coefficient of light in canopy; and $K=$ light extinction coefficient (square meter of the land per square meter of leaf).

Coefficients of reflection in canopy are calculated based on diffusion factor of single leaves as follows (Nassiri \& Elgersma, 1998).

$$
P=[(1-\sqrt{(1-\sigma)}) /(1+\sqrt{(1-\sigma)})] *[2 / 1+1.6 \sin \beta]
$$

Equation (2)

where, $\sigma=$ diffusion coefficient of single leaves for visible radiation, whose amount for most agricultural species is nearly $0.2 ; \beta=$ Height of the solar.

Although Equation (1) is suitable for pure culture, the cumulative leaf area of any species above a specified height should be separately calculated in mixed cultures where there is more than one competing species and where species have different heights.

In this case, equation (1) will be as follows,

$$
I_{h}=(1-p) I_{o} \exp \left(-\sum K_{i} L_{h, i}\right) \quad \text { Equation (3) }
$$

where, $I_{h}=$ Radiation in height (joules per square meter per second); $I_{0}=$ Radiation above the canopy (joules per square meter of land per second); $L_{h, i}=$ Cumulative leaf area index (toward bottom) of species $i$ in each height of the canopy; and $K_{i}=$ Extinction coefficient of species $i$ (square meters of land per square meter of leaves).

Cumulative leaf area is calculated based on any relationship between leaf area density and plant height. Leaf area density or $L A D$ shows the leaf area around a particular point from canopy height (square meter of leaf per land's square meter per height).

$L A D$ is used in different models to calculate profile and light interception in

Planta Daninha, Viçosa-MG, v. 28, n. 3, p. 455-462, 2010 
mixed species (Kropff et al., 1993). Different functions are considered in different models for the leaf canopy distribution. Kropff et al. (1993) considered leaf area distribution in the canopy as a parabola in INTERCOM model. In the parabolic function, it is assumed that the maximum leaf area of any species can be obtained in 50 percent of height. In mixed culture of most species, there is no parabolic distribution of leaf area. For example, in mixed culture of clover with grass, the clover has more leaf area density ( $L A D)$ at the upper section of the canopy (Nassiri \& Elgersma, 1998). The results of this experiment also suggested that there is more leaf area in upper canopy layers of Common cocklebur, compared to corn. Therefore, leaf area distribution is not in a parabolic form, which is the reason why triangular function, as follows, was used instead of parabolic $L A D$ function in this experiment (Nassiri \& Elgersma, 1998).

$$
\begin{aligned}
& L A D_{h} \quad L d, m \frac{\left(\begin{array}{ll}
H & h
\end{array}\right)}{\left(\begin{array}{ll}
H & h_{m}
\end{array}\right)} h_{m} \quad h \quad H \quad \text { Equation (4) } \\
& L A D, h \quad L d, m \frac{h}{h_{m}} \quad 0 \quad h \quad h_{m} \quad \text { Equation (5) }
\end{aligned}
$$

where, $L A D_{h}=$ leaf area density at the intended height $\left(\mathrm{m}^{2} \mathrm{~m} 3\right) ; L A D,{ }_{h}=$ maximum leaf area density of the leaf $\left(L A D_{m}\right) ; h_{m}=$ height where maximum leaf area density can be seen $(\mathrm{cm})$; and $\mathrm{H}=$ total canopy height.

The following relationship can be used,

$$
L_{d, m} \frac{2 L A I}{H} \quad \text { Equation (6) }
$$

After calculating the $L A D$ based on the above relationships, the cumulative leaf area index (toward bottom) of each species $i$ in each canopy height can be calculated as follows:

$$
L_{h, i} \frac{1 \frac{h_{i}}{H_{i}}}{1 \frac{h_{m, i}}{H_{i}}} L_{i} \quad h_{m, i} \quad h_{i} H_{i}
$$

Equation (7) I

$$
L_{h, i} \quad 1 \frac{h_{i}}{H_{i} * h_{m, i}} L_{i} \quad 0 \quad h_{i} \quad h_{m, i}
$$

Equation (7)

were, $L_{h, i}=$ cumulative leaf area index of species $i$ at height $H ; L i=$ leaf area index of the whole species $i$; $h i=$ intended height in the canopy; $H=$ height of whole species $i ; h_{m}=$ height where maximum $L A D$ has been seen

After placing cumulative leaf area index $\left(L_{h, i}\right)$ in equation 3 , the amount of PAR radiation can be calculated at each height in the mixed canopy.

\section{RESULTS AND DISCUSSION}

\section{Validation of model}

\section{Vertical distribution of leaf area}

In order to validate the model, data collected during the experiment were examined and compared with the data provided by the model. The results suggested that the triangular function of leaf area density was appropriate for the studied species, and has provided a suitable prediction of real data (Figure 1). Corn $L A D m$ was shown to be smaller than Common Cocklebur $L A D m$, indicating that there is more competitive power in corn, compared to Common cocklebur (Figure 1). Maximum $L A D$ of corn in competition with that of Common cocklebur was seen at the height of $100 \mathrm{~cm}$ (57 percent of total height). Maximum $L A D$ of Common cocklebur was seen at the height of $50 \mathrm{~cm}$ (58 percent of total height) (Figure 1). Comparison of $L A D$ values in different density showed that the height where maximum $L A D$ can be observed is affected by the density, and its amount will be increased with the increase in density of corn (Figure 1). Also, it seems that with increase in density, competition for light will be increased and that the height not only will be affected, but also will the distribution pattern of the leaf canopy. Height and leaf area index are regarded as two factors determining competitive advantage in crop-weed mixed canopy. It is believed that the species with more leaf area and height will be more successful (Holt, 1995). 

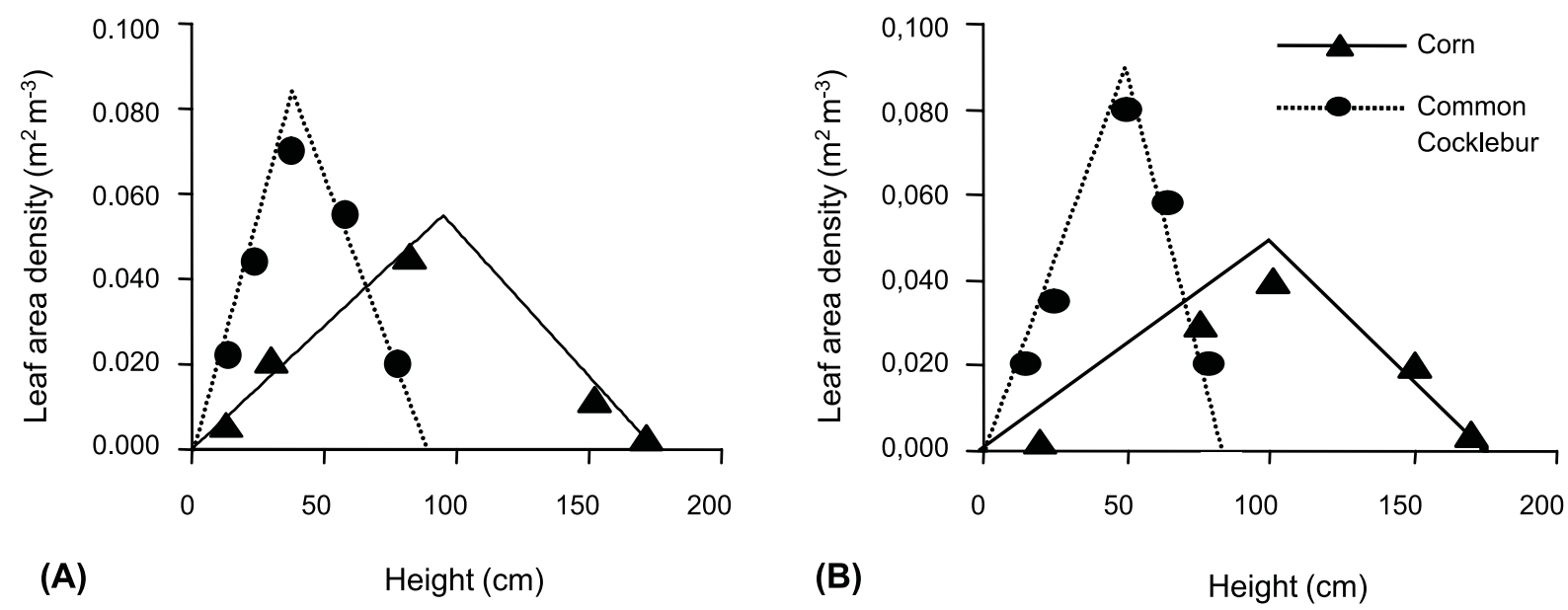

Figure 1 - Vertical distribution of corn and Common cocklebur leaf area at 90 days after planting at densities of corn of 7.5 (A) and 9.5 (B) plants per meter of row. and the highest density of Common cocklebur (8 plants per meter of row).

\section{Radiation interception by mixed canopy}

In addition to leaf area, the radiation absorbed by the mixed canopy was also used to validate the model. For this reason, the radiation absorbed by mixed canopy was simulated for any density of corn, which highest density in the experiment was used for weed. Then, the actual measured values of radiation were compared with the values predicted by the model, whose results suggested that in all cases, an appropriate model of estimation is provided from the actual data (Figure 2). In this model, extinction coefficient was considered to be constant. Extinction coefficient is equal to 0.65 for corn and 0.7 for Common cocklebur (these values were calculated through parameter model to achieve best compliance with experimental data at a constant density, and then were used in other cases). Depreciation coefficient of vertical leaf species (monocotyledonous) was reported to be between 0.4-0.7 and horizontal leaf species (dicotyledonous) to be between 0.651 (Monteith, 1969).

\section{Testing model sensitivity}

To evaluate the amount of model sensitivity to each of the parameters affecting it, leaf area index, and the height where maximum leaf area density $(\mathrm{hm})$ is placed, as well as extinction coefficient $(\mathrm{K})$ of any species were changed between 5 and 30 percent. And in any case, the amount of light interception was determined by the model for each species (Table 1). In case 1, values of parameters will be the same for both species, and the amount $\mathrm{hm}$ was considered in half canopy (parabolic distribution). In this condition, the light absorbed by both species was equal (Table 1). Among the parameters studied, the height change showed the biggest effect on light

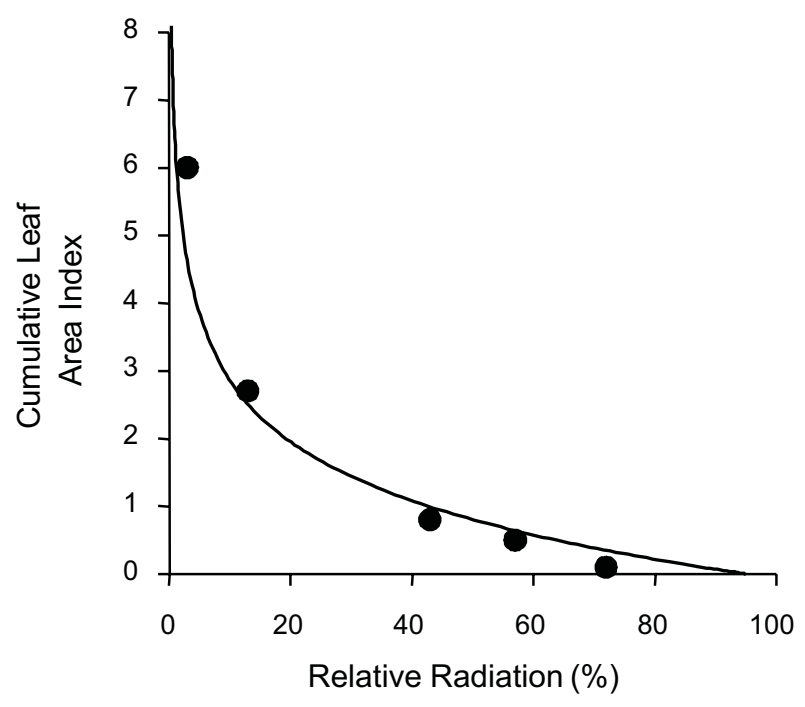

Figure 2 - Light extinction of mixed canopy of corn and Common cocklebur in 90 days after planting at lowest density of corn (7.5 plants per meter of row) and the highest density of Common cocklebur ( 8 plants per meter of row). 
interception, so that the height of corn (species 1) increased by 30 percent compared to case 1 , and by 28 percent compared to weed (Table 1). It is in the case that 30 percent of increase in leaf area index and $\mathrm{hm}$, and/or of decrease in the extinction coefficient, caused the increases of 15,15 and 13 in light interception for corn compared to case 1 and increases of 12 percent in light interception compared to weed (Table 1). So, any species with more height and less depreciation coefficient or with more leaf area density in upper canopy layers will be able to intercept more light and to have higher competition ability.

\section{Determination of the ideal type of corn in competition with weed for light}

Model sensitivity test showed that height, leaf area index, the height where the maximum leaf area index can be seen $(\mathrm{hm})$ and extinction coefficient of species are important in light interception (Table 1). For this reason, these treats were used when designing the ideal type of corn. Considering that the agricultural crop yield rate is a function of the light received and of light consumption efficiency, it can be said that those species that receive a greater share of light would have a higher grain yield. The amount of light received for use in designing the ideal type of corn depends on the plant density. Considering that the results suggested that the highest grain yield of corn is achieved in density of 9.5 plants per meter of row (data not shown), the amount of the light received by the corn in pure culture was considered as basis in the density above. However, corn was approximately two times higher than common cocklebur in the intended density (Figure 3), as well as receiving more light (nearly 3 times), the ideal type of corn was designed in competition with two weeds for receiving light until the time of tasseling (70 days after planting). Real values relating to parameters of height, leaf area index, the height where maximum $L A D$ has been seen $(\mathrm{hm})$ and the extinction coefficient obtained from experiments were placed in the mentioned density of the model, and the amount of light received in this case was computed by the model. Then, with the assumption that the ideal type of corn should intercept at least 80 percent of light absorbed in pure culture, in competition with the weeds, the ideal corn type was designed. In the experiment that is performed for the purpose of comparing competition of broadleaf weeds and grasses with corn, it was specified that 76 percent of the corn's leaf area and only 23 percent of the weeds' biomass have been placed above a meter over the surface of the soil. In these circumstances, the competition of weed for interception of the light that reached the canopy was weak, because about 75 percent of the input radiation is absorbed by the upper layer of corn coverage. However, even if competition for light interception is relatively weak, the same small amount of light passed through corn canopy is sufficient for weed growth and competition will be continued through interference for exploiting other resources (Tollenar, 1994).

Table 1 - Results of model sensitivity test in different conditions and the percentage of light absorbed by each species

\begin{tabular}{|c|c|c|c|c|c|c|c|c|c|c|c|c|c|c|c|c|c|c|c|c|c|c|c|c|c|}
\hline \multirow{2}{*}{ Parameter } & \multicolumn{25}{|c|}{ Case } \\
\hline & 1 & 2 & 3 & 4 & 5 & 6 & 7 & 8 & 9 & 10 & 11 & 12 & 13 & 14 & 15 & 16 & 17 & 18 & 19 & 20 & 21 & 22 & 23 & 24 & 25 \\
\hline LAI1 & 3.5 & 3.67 & 3.82 & 4.02 & 4.2 & 4.37 & 4.55 & 3.5 & 3.5 & 3.5 & 3.5 & 3.5 & 3.5 & 3.5 & 3.5 & 3.5 & 3.5 & 3.5 & 3.5 & 3.5 & 3.5 & 3.5 & 3.5 & 3.5 & 3.5 \\
\hline LAI2 & 3.5 & 3.5 & 3.5 & 3.5 & 3.5 & 3.5 & 3.5 & 3.5 & 3.5 & 3.5 & 3.5 & 3.5 & 3.5 & 3.5 & 3.5 & 3.5 & 3.5 & 3.5 & 3.5 & 3.5 & 3.5 & 3.5 & 3.5 & 3.5 & 3.5 \\
\hline H1 & 130 & 130 & 130 & 130 & 130 & 130 & 130 & 136 & 143 & \begin{tabular}{|l|}
149 \\
\end{tabular} & 156 & 162 & \begin{tabular}{|l|}
169 \\
\end{tabular} & 130 & 130 & \begin{tabular}{|l|}
130 \\
\end{tabular} & 130 & 130 & 130 & 130 & 130 & 130 & 130 & 130 & 130 \\
\hline $\mathrm{H} 2$ & 130 & 130 & 130 & 130 & 130 & 130 & 130 & 130 & 130 & 130 & 130 & 130 & 130 & 130 & 130 & 130 & 130 & 130 & 130 & 130 & 130 & 130 & 130 & 130 & 130 \\
\hline $\mathrm{Hm} 1$ & 65 & 65 & 65 & 65 & 65 & 65 & 65 & 65 & 65 & 65 & 65 & 65 & 65 & 68 & 71 & 75 & 78 & 81 & 85 & 65 & 65 & 65 & 65 & 65 & 65 \\
\hline $\mathrm{Hm} 2$ & 65 & 65 & 65 & 65 & 65 & 65 & 65 & 65 & 65 & 65 & 65 & 65 & 65 & 65 & 65 & 65 & 65 & 65 & 65 & 65 & 65 & 65 & 65 & 65 & 65 \\
\hline K1 & 0.7 & 0.7 & 0.7 & 0.7 & 0.7 & 0.7 & 0.7 & 0.7 & 0.7 & 0.7 & 0.7 & 0.7 & 0.7 & 0.7 & 0.7 & 0.7 & 0.7 & 0.7 & 0.7 & \begin{tabular}{|l|} 
\\
\end{tabular} & 0.77 & 0.81 & 0.84 & \begin{tabular}{|l|}
0.88 \\
\end{tabular} & 0.91 \\
\hline K2 & 0.7 & 0.7 & 0.7 & 0.7 & 0.7 & 0.7 & 0.7 & 0.7 & 0.7 & 0.7 & 0.7 & 0.7 & 0.7 & 0.7 & 0.7 & 0.7 & 0.7 & 0.7 & 0.7 & 0.7 & 0.7 & 0.7 & 0.7 & 0.7 & 0.7 \\
\hline PAR1 & 0.47 & 0.48 & 0.49 & 0.50 & 0.51 & 0.52 & 0.53 & 0.50 & 0.53 & 0.55 & 0.57 & 0.59 & 0.61 & 0.48 & 0.49 & 0.50 & 0.51 & 0.52 & 0.54 & 0.46 & 0.45 & 0.44 & 0.43 & 0.42 & 0.41 \\
\hline PAR2 & 0.47 & 0.46 & 0.45 & 0.44 & 0.43 & 0.42 & 0.41 & 0.44 & 0.41 & \begin{tabular}{|l|}
0.39 \\
\end{tabular} & 0.37 & 0.34 & \begin{tabular}{|l|}
0.33 \\
\end{tabular} & 0.46 & 0.45 & 0.44 & \begin{tabular}{|l|}
0.43 \\
\end{tabular} & 0.42 & 0.41 & 0.48 & \begin{tabular}{|l|}
0.49 \\
\end{tabular} & 0.50 & 0.52 & 0.53 & 0.53 \\
\hline
\end{tabular}




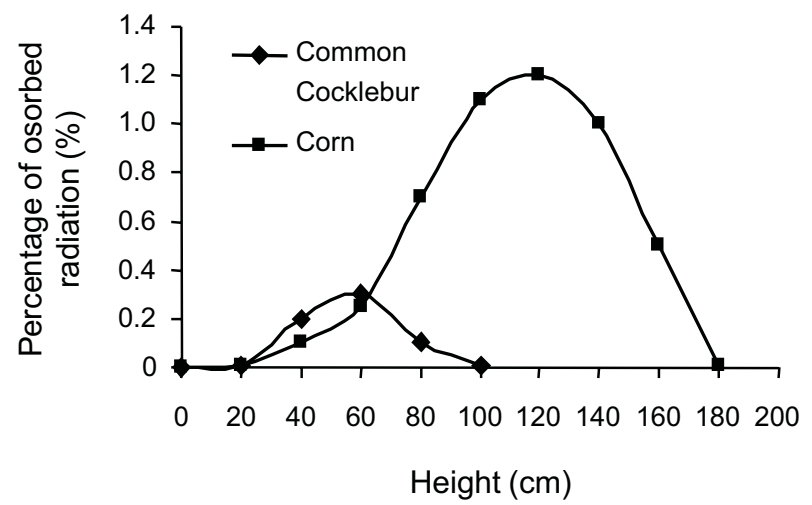

Figure 3 - Percentage of the absorbed radiation per centimeter of the canopy height in lowest densities of corn at the highest density of Common cocklebur.

Real values of the parameters above were used for weed at the highest density ( 8 plants per meter of row). Then, values of parameters were changed for corn, and the amount of the light absorbed by any species was determined in each case. Countless number of cases were evaluated, among which the cases absorbing $80 \%$ of the light (compared to their pure culture, i.e. in a density of 9.5 plants per meter of row) were selected. Then, those cases in which the corn had a desirable limit of the traits above were screened, and were introduced as the ideal type of corn in competition with weed.

Light interception was compared in normal and ideal type corn at the time of tasseling (Table 2). This comparison showed that in density of 9.5 corn plants per square meter at the highest density of Common cocklebur (8 plants per meter of row), the contribution of normal type corn and Common cocklebur to the light interception were 0.54 and 0.23 , respectively, while these values were 0.70 and 0.23 in the ideal type of corn (Table 2). Comparison of light interception rate in competition with Common cocklebur shows that ideal type of corn in competition with the normal Common cocklebur has an increase of 2.09 to 2.90 in leaf area index, compared to the normal case (Table 2). Overall, it can be said that the biggest difference of the ideal type of corn in competition with Common cocklebur is related to the leaf area index which suggests that the corn needs to maintain leaf area index and increase it at this stage. This can be, to some extent, achieved through applying management practices including increase in the density of agricultural plant, just as the competitive power of the weeds was decreased by increasing the corn density to the rate of 9.5 plants per square meter.

Ranges of height changes in the ideal type of corn were between 90 to $95 \mathrm{~cm}$ in competition with Common cocklebur, which it is possible to achieve (Table 2). There was a correlation between the percentage of weedabsorbed radiation and the percentage of the corn seed yield loss (Figure 4). The percentage

Table 2 - Comparison of the parameters used in model in normal case with the ideal types of corn in competition with Common cocklebur

\begin{tabular}{|l|r|r|r|}
\hline Parameter & Case1 & Case2 & Case3 \\
\hline LAI1 & 2.09 & 2.9 & 2.9 \\
\hline LAI2 & 3.51 & 3.51 & 3.51 \\
\hline $\mathrm{H} 1$ & 85 & 90 & 95 \\
\hline $\mathrm{H} 2$ & 75 & 75 & 75 \\
\hline $\mathrm{Hm} 1$ & 80 & 85 & 80 \\
\hline $\mathrm{Hm} 2$ & 55 & 55 & 55 \\
\hline $\mathrm{K} 1$ & 0.65 & 0.5 & 0.5 \\
\hline $\mathrm{K} 2$ & 0.7 & 0.7 & 0.7 \\
\hline PAR1 & 0.54 & 0.7 & 0.7 \\
\hline PAR2 & 0.39 & 0.23 & 0.23 \\
\hline
\end{tabular}

Case 1: real cases of corn in density of 9.5 plants and weed at highest density ( 8 plants per meter of row), and Cases 2 and 3 : ideal types of corn; LAI1 and LAI2 are leaf area indexes of corn and weed, respectively, and $\mathrm{H} 1$ and $\mathrm{H} 2$ are heights of corn and weed; $\mathrm{Hm} 1$ and $\mathrm{Hm} 2$ are corn and weed heights where there are maximum leaf area indexes, respectively for corn and weed; K1 and $\mathrm{K} 2$ are extinction coefficients of corn and weed, respectively; PAR1 and PAR2 are ratio of absorbed radiation for species 1 (corn) and 2 (Common Cocklebur)

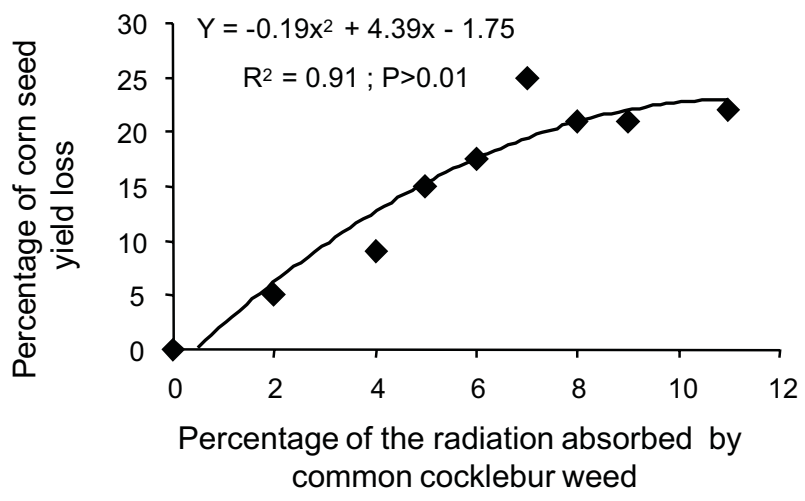

Figure 4 - Relationship between the percentage of radiation absorbed by the weed and the percentage of corn seed yield loss. 
of the corn seed yield loss was increased with an increase in the percentage of the radiation absorbed by weed. According to the interception of about 15 percent of radiation by Common cocklebur (Figure 4), this weed will be followed by maximum corn seed yield loss, so it seems that the factors other than light can cause corn seed yield loss. Comparison of parameter $\mathrm{r}$ (Equation 8) about the Common cocklebur showed that the value of this parameter concerning Common cocklebur is equal to 0.24 (difference based on $t$ test was significant at the level of 0.01).

$$
Y L \% \frac{Y L_{\max }}{\left(1 b^{*} \exp \left(r^{*} 1\right)\right)} \quad \text { Equation (8) }
$$

Where, $Y L=$ Percentage of corn seed yield loss; $Y L_{\max }=$ maximum percentage of yield loss; $b=$ percentage of the radiation absorbed by the weed; and $r=$ average rate of the corn seed yield loss in reaction to loss of the radiation absorbed by the corn.

The results suggested that the triangular function of leaf area density was appropriate for the corn and common cocklebur species, and has provided a suitable prediction of real data and corn will be able to preserve their yield as much as acceptable if it can increase its light interception rate to $80 \%$ of pure culture until the stage of tasseling.

\section{LITERATURE CITED}

ANTEN, N. P. R.; HIROSE, T. Intraspesific difference in above-ground growth pattern result in spatial and temporal partitioning of light among species in a tall grass meadow. $\mathbf{J}$. Ecol., v. 87, n. 2, p. 583-597, 1999.

BERKOWITZ, A. R. Competition for resource in weed crop mixture in weed management In: ALTIERI, M. A.; LIBMAN M., (Eds.). Agroecosystem: Ecological approaches. Boca Raton: CRC Press, 1988. p. 111-131

CALDWELL, M. M. Plant architecture and resource competition. In: SCHULZE, E. D.; WOLFER, H. Z. Ecological studies. NewYork: Springer Berlin Heidelberg, 1987. p. $166-179$.
HIROSE, T. et al. Modeling canopy photosynthesis and optimal leaf area index in response to co 2 elevation in annual plant stands. Ecology, v. 78, n. 4, p. 2239-2350, 1997.

HIKOSAKA, K.; SUDOH, S.; HIROSE, T. Light acquisition and use of individuals' competition in a dense stand of an annual herb, Xanthium canadense. Oecologia, v. 18, n. 3, p. 388-396, 1999.

HOLT, A. J. S. Plant response to light: a potential tool for weed management. Weed Sci., v. 43, n. 2, p. 474-482, 1995.

KROPFF, M. J., van LAAR H. H.; BERGE H. F. M., (Eds). ORYZAI: Abasic model for irrigated lowland Rice production. Los Banos: International Rice Research Institute, 1993. p. 89.

KEATING, B. A.; CARBERRY, P. S. Resource capture and use in intercropping Solar radiation. Field Crops Res., v. 34, n. 3, p. 273-301, 1983.

MONTEITH, J. L. Light interception and radiative exchange in crop stands. In: EASTIN, I. D. et al. (Eds) Physiological aspects of crop yield. Madison: American Society of Agronomy, Crop Science Society of America, 1969. p. 89-111.

NASSIRI, M.; ELGERSMA, A. Competition in perennial ryegrass-white clover mixture, Leaf charachteristics, light interception and dry matter production during regrowth. Grass Forage Sci., v. 53, n. 1, p. 367-379, 1998.

RHODES, I.; STERN, W. R. Competition for light. In: WILSON, J. R (Ed). Plant relation in pastures. East Melborne: CSIRO, 1978. p. 175-189

SINOQUET, H. et al. Modelling the radiative balance of the component of a well mixed canopy: application to a white clover-tall fescue mixture. Acta Oecol., v. 11, n. 2, p. 469-478, 1996.

SPITTERS, C. J. T.; AERTS, R. Simulation of competition for light and water in crop-weed associations. Aspects Appl. Biol., v. 4, n. 2, p. 467-484, 1983

TOLLENAR, M.; POBO, P. A.; SWANTON, E. J. Effect of crop density on weed in terference in maize. Agron. J., v. 86, n. 4, p. 591-595, 1994.

TOLLER, J. E.; GUICE, J. R. Interference between johnsongrass Sorghum halepense) smooth pigweed (Amaranthus hybriduse) and soybeans (Glycinemax). Weed Sci., v. 44, n. 3, p. 331-338, 1996 